\title{
The relation between evaluative stances and narratological elements in an audio description script for theatre
}

\author{
A relação entre as marcas \\ avaliativas e os elementos \\ narratológicos em um roteiro de \\ audiodescrição para o teatro
}

Janaína Vieira Taillade Abud ${ }^{*}$

Vera Lúcia Santiago Araújo**

\footnotetext{
* Master's Degree in Applied Linguistics from State University of Ceará (UECE). Currently studying to obtain a PhD in Linguistics Studies from Federal University of Minas Gerais (UFMG). Researcher in audio description. E-mail: janataillade@gmail.com. iD ORCID: 0000-0003-1838-7664.

${ }^{* *} \mathrm{PhD}$ in Arts from USP with post-doctorate from UFMG. Currently, teaching and advising at PostGraduate Program in Applied Linguistics (PosLA) and Post-Graduate Program in Education (PPGE) from State University of Ceará. Researcher level 2 for CNPq. Has professional experience in the field of Applied Linguistics, especially in Translation, working mainly with the following subjects: audiovisual translation, subtitle for the deaf and hard of hearing and audio description. E-mail: vera.santiago@uece.br. iD ORCID: 0000-0002-4654-8747.
} 
Abstract: The question of neutrality in audio description (AD) has been discussed by professionals and researchers. Following several studies started by Praxedes Filho and Magalhães $(2013,2015)$, this article analyzes if evaluative stances identified via the Appraisal System (AS) in the AD script of the play Miralu and the Magic Telescope (Miralu e a Luneta Encantada) can be related to narratological elements. For this purpose, we have adopted a corpus-based methodology, using categories of AS, up to the second level of delicacy, as well as narratological ones based on Jiménez Hurtado (2010) and Pavis $(2011,2015)$. As a result, we have found 166 co-occurrences of evaluative stances and narratological elements, among which there are $73(43,98 \%)$ associated to gesture, $42(25,30 \%)$ to costume and $40(24,10 \%)$ to lighting descriptions. These findings suggest that these co-occurrences are probably not coincidental, taking into consideration that previous studies have already pointed out the importance of subjective description in the AD scripts.

Keywords: Audio Description; Appraisal System; Narratology; Theatre.

Resumo: A questão da neutralidade na audiodescrição $(A D)$ vem sendo discutida por profissionais e pesquisadores. Dando continuidade a vários estudos iniciados por Praxedes Filho e Magalhães $(2013,2015)$, este artigo tem por objetivo analisar se as marcas avaliativas, identificadas por meio do Sistema de Avaliatividade (SA), no roteiro de audiodescrição da peça Miralu e a Luneta Encantada, podem ser relacionadas aos elementos narratológicos. Para tanto, adotamos uma metodologia baseada em corpus, utilizando as categorias do SA, até o Segundo nível de delicadeza, assim como as categorias narratológicas baseadas em Jiménez Hurtado (2010) e Pavis $(2011,2015)$. Como resultado, encontramos 166 co-ocorrências de marcas avaliativas e elementos narratológicos, entre os quais temos $73(43,98 \%)$ associadas a gestos, $42(25,30 \%)$ a figurino e $40(24,10 \%)$ a iluminação. Esses resultados sugerem que essas co-ocorrências podem não ser coincidência, levando em consideração que estudos anteriores já apontavam a importância de descrições subjetivas em roteiros de audiodescrição.

Palavras-chave: Audiodescrição; Sistema de Avaliatividade; Narratologia; Teatro. 


\section{Introduction}

The growing concern about the access of disabled people ${ }^{1}$ to audiovisual products turned audio description into an important topic for researchers. The $A D$ concept is associated with the field of Accessible Audiovisual Translation (JIMÉNEZ HURTADO 2010), as a way to promote accessibility of audiovisual products to visually impaired people. In theatrical plays, for instance, audio description consists of the narration or description of visual elements and it usually fills the blank spaces between the speeches of dialogues or between relevant sounds.

One of the issues discussed by scholars and professionals in this field is the possibility of having neutrality while describing visual elements. The fact is that $A D$ international official parameters, like the American Standards for Audio Description and Code of Professional Conduct for Describers (2009) and the French Charte de Qualité de l'Audiodescription (2008), defend that the describer should always be neutral, describing only what he sees, avoiding subjectivity or interpretation.

However, several studies, some of which by Praxedes Filho (PRAXEDES Filho; Magalhães 2013; Praxedes Filho; Magalhães 2015; Silva; Oliveira Júnior 2016; Farias Júnior 2016; Praxedes Filho; Santos; Farias Junior 2015; Araújo; PraXedes; Abud 2017; ARRAes 2017; Abud 2018) question this rule. Based on the conception of language provided by Systemic Functional Linguistics (SFL), these authors investigate the possibility of any text being neutral. Using Martin and White's Appraisal System (2005), they claim that there is no neutrality in the $A D$ scripts of paintings, movies, monuments and plays.

\footnotetext{
${ }^{1}$ In Brazil, this inclusion is materialized in legislation that aims to guarantee access to culture and education, such as: the Accessibility Law (Federal Law 10.098/2000) and the Federal Law $5.626 / 2005$, which regulates the uses of Brazilian Sign Language (Libras). It can also be mentioned the Decree 5.296/2004, which implements the Accessibility Law and the Federal Ordinance $188 / 2010$ that determines the obligation of audio description in television.
} 
This paper corroborates that view through an analysis of the audio description script of a play called Miralu e a Luneta Encantada (2016) (henceforth Miralu and the Magic Telescope), relating the evaluative stances to the construction of the narrative. The play tells the story of a visually impaired young girl named Miralu. After she becomes an orphan, she is raised by her uncle Lucrécio and her aunt Carola, who have a son called Papito at the same age as Marilu. In a monologue, Miralu expresses her dissatisfaction with her disability and, to fulfill her wish to see, a fairy godfather appears and gives her a magic telescope. She can see perfectly through the telescope for up to a minute. After that, she starts seeing only people's negative behavior.

For our purposes, tags were created according to the Appraisal System categories of 'attitude', 'engagement' and 'graduation', up to the second level of delicacy. Second, we studied the narratological elements, using the theoretical framework of narratology (JIMENEZ HURTADO 2010) in an interface with Pavis' theatrical narrative (2015). This interface is the focus of this article, which contributes to theatrical audio description. In the following sections, we explain the Appraisal System, followed by filmic and theatrical narratology in audio description, we proceed with research method, findings, and discussion. At the end we present the conclusions and possible outcomes of this research.

\section{The Appraisal System}

In Systemic Functional Linguistics (SFL), language is conceived as a stratified system in which the speaker or writer makes choices from among potential available resources. These choices are made in a social context of use, where language fulfills functions. Linguistic meanings are generated by a social system and each text is an instantiation of language that needs to be understood in the context of culture and situation. (HALLIDAY 1978) 
In the context of situation, according to the Hallidayan view, linguistic features can be associated under three headings: field, tenor and mode. These dimensions are realized in the language strata respectively by three metafunctions: ideational (building experience), interpersonal (establishing relations) and textual (organizing discourse). The strata of language are those of: semantics; lexicogrammar; and phonology or graphology. The Appraisal System (AS) integrates the interpersonal metafunction because it points the way the speaker/writer shows his/her subjectivity in relation to what is said or written. It is situated in the semantics stratum since it helps construct meaning. (HALLIDAY 1978)

Our choices of potential evaluative resources are described in a more refined or detailed way as we go through levels of delicacy, according to Martin and White (2005). To achieve the goals of this study, we used AS only up to the second level of delicacy. In terms of the first level of delicacy, the subjective stances can be divided in three categories: 'attitude'2 (related to feelings), 'engagement' (related to the dialogical dimension) and 'graduation' (related to ways of quantifying, intensifying feelings or linking them to prototypical meanings). As to the second level of delicacy, when we choose 'attitude', there are three simultaneous systems: TYPES OF ATTITUDE, POLARITY and ATTITUDE strategies. Beginning with the system TYPES OF ATTITUDE, we have the choices: 'affect' (emotional aspect), 'judgement' (ethical aspect) and 'appreciation' (esthetical aspect). POLARITY indicates if the feeling can be qualified as having good value ('positive'), bad value ('negative') or indefinite value ('ambiguous'). Attitude strategies can be 'invoke' (implicit) or 'inscribe' (explicit). The term 'affect' refers to emotions. An example in our corpus is categorized as an emotion ('attitude''affect') in a positive and explicit way and is signaled in bold²:

\footnotetext{
${ }^{2}$ As a convention, we adopted in this article the following notation: the terms used to identify the different kind of appraisal, along the levels of delicacy, are written between single quotation marks and in lower case letters. On contrary, the terms used to explain the range of following choices in the system network are written in capital letters and without quotation marks.

${ }^{3}$ In this article, all translations are ours.
} 
(1) The master and the Lunatic disappear. Miralu looks for them on stage. She gets happy and anxious to look through the telescope. ${ }^{4}$

The choice of 'judgement' identifies ethical judgements. As an example, we have the following excerpts:

The lights fade. Aunt Carola and uncle Lucrécio (2) dance holding Neco's arms and legs. Sometimes, (3) they pull and stretch Neco's arms and legs. (4) They take Neco down to the floor. ${ }^{5}$

Passages (2), (3) and (4) are regarded as 'judgement' because, according to the description, the puppet Neco is being physically threatened by Carola and Lucrécio and this behavior is perceived as bad. Both of them are negative and implicit (invoked).

By 'appreciation', we mean esthetical appraisals. An example from the corpus is the following utterance:

(5) Both come on stage. Blue lights illuminate them. ${ }^{6}$

Due to the fact that this passage describes an esthetic aspect, it illustrates an esthetical evaluation ('attitude'-'appreciation'), in an explicit way ('inscribe'), but it lets the audience interpret freely if the esthetical language of luminous color means something positive or negative (thus categorized as 'ambiguous').

Regarding 'engagement', according to the TYPES OF ENGAGEMENT, the stances can be 'monoglossic' or 'heteroglossic', depending on their dialogical characteristics. Heteroglossic discourse opens to other voices, while monoglossic does not. In example 6 , the second sentence produces counterexpectancy, bringing another voice to the text.

(6) Miralu tries to remove the telescope from her eye, but she does not succeed. ${ }^{7}$

\footnotetext{
${ }^{4}$ Source text: 0 mestre e o lunático somem. Miralu procura os dois pelo palco. Ela fica feliz e ansiosa para olhar pela luneta.

${ }^{5}$ Source text: As luzes reduzem a intensidade. Tia Carola e tio Lucrécio dançam segurando os braços e as pernas do Neco. Em alguns momentos, eles puxam e esticam os braços e as pernas do boneco. Eles derrubam o Neco no chão.

6 Source text: Os dois sobem no palco. Luzes os iluminam.
} 
Concerning the system network of evaluation, the choice 'graduation' means that a feeling is graduated upward ('up-scale') or downward ('downscale'). When a feeling is intensified or quantified with an imprecise measure it is said to have 'force'. On the other hand, when it varies on degree of prototypicality it is said to have 'focus'. In this example, we identify an intensifier in the act of entering, when uncle Lucrécio is introduced to the public and the way of describing his action gives an idea of an accelerated pace:

(7) Uncle Lucrécio enters in a hurry, talking on a cell phone. ${ }^{8}$

Figure 1 gives a general overview of AS up to the second level of delicacy, even though it does not show all the details of the system network already explained.

Figure 1 - Appraisal System up to the second level of delicacy.

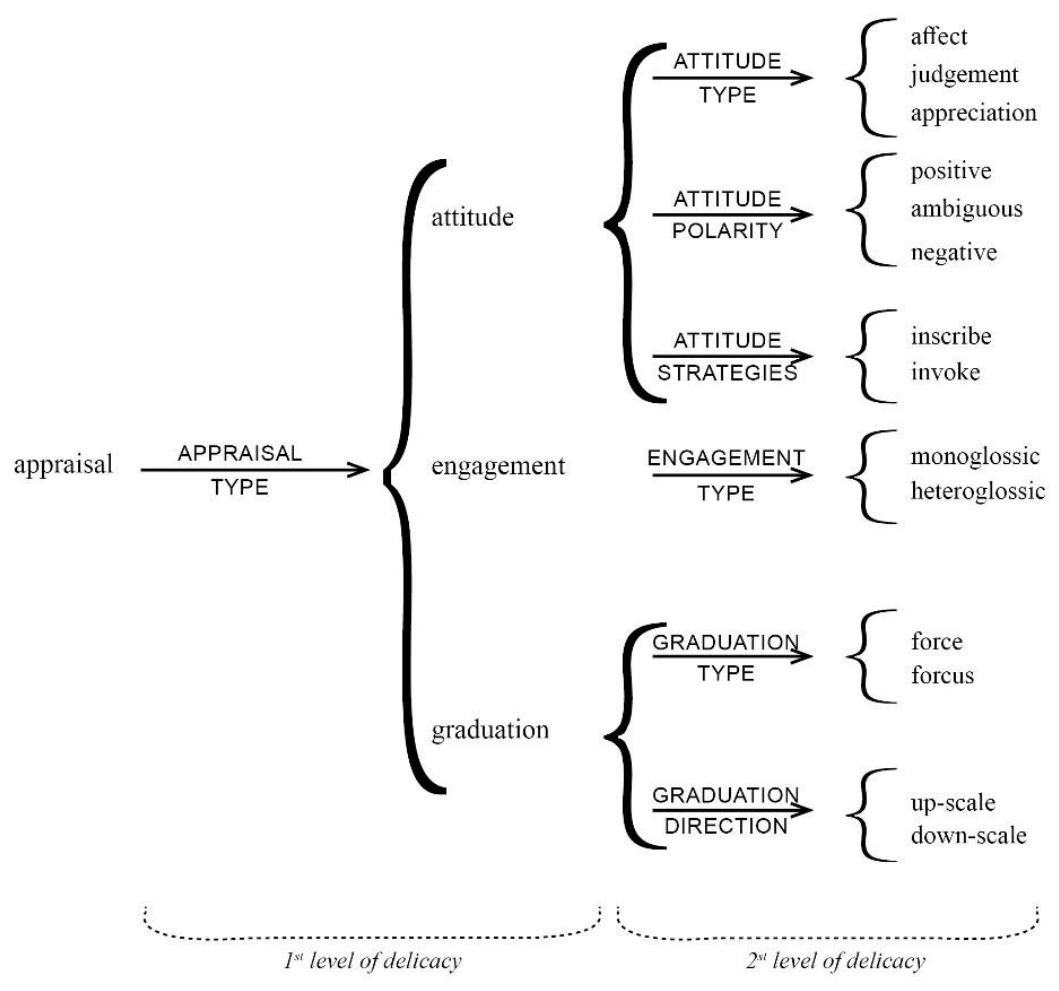

${ }^{7}$ Source text: Miralu tenta retirar a luneta do olho, mas não consegue.

${ }^{8}$ Source text: Tio Lucrécio entra apressado, falando ao telefone celular. 
Having understood this system network, we can proceed to explain narratology in audio description and how AS can be related to it.

\section{Filmic and theatrical narratology in audio description}

In the sphere of our specific interests, relating evaluative stances to $A D$ elements, we should begin by emphasizing that studies in $A D$ suggest that the more subjective a description of a narratological element is, the longer it remains in our memory. At least, that interpretation is sometimes recommended in AD. For instance, Fresno et al (2016) conducted an experimental study about character descriptions and concluded that those with "semantic" content (when audio describers interpret what they see) are better to memorize. Vercauteren and Remael (2014) have analyzed descriptions of spatio-temporal background (setting, accessories, elements related to time, etc.) in AD. They observed that symbolic elements, compared to functional ones, need a more interpretative description to convey implicit meaning.

Mazur (2014) carried out a research on AD description about gesture and facial expressions. She reinforced the importance of interpretation in the case of these two items. Although alerting against false descriptions, she argued in favor of interpretation, in the face of difficulties in describing details due to time constraints or to give an intelligible description. All these reflections corroborate the importance of studying $A D$ from the Appraisal System perspective, and they also lead us to the study of narratological elements in audio description.

Jiménez Hurtado (2010) analyzed a film narrative to produce an audio description script. She divided this narrative in three structures: narratological level (narrative itself, i.e. how the story is built), 
cinematographic level (camera language) and grammatical-discursive level (the way $A D$ verbalizes visual information). Only the narratological level will interest us for our objective of adapting it to the theatrical $A D$ perspective. Camera language does not apply to theatre language and verbal language has already been seen here through the Appraisal System.

Jiménez Hurtado has distinguished three aspects of narratology: characters (who), action (what) and background (time and space). In addition, at the same level, she has defined a category of visual/verbal elements that does not match theatrical language, because it refers to filmic titles, subtitles and credits. With respect to the three first mentioned aspects, the author created tags covering characters and background, arguing that actions encompass all of them.

The categories that refer to characters are identification, physical attributes (age, ethnicity, aspect, costume, facial expression and body language) and states (emotional, physical and mental). Tags about background are: settings, accessories, lighting and color. These categories were adapted to theatrical language, in accordance with Pavis $(2011,2015)$. Thus, "physical aspect" (physical attribute) was limited to "hair", "size" and "age". "Acting" included "gesture" and "facial expression", and covered Jiménez Hurtado's emotional, physical and mental states. We separated "costume" and "make-up" from "physical aspects", arguing for their bigger importance to the theatre. With respect to background, we kept "setting" and "lighting", but we discarded color and accessories, because we included them as a part of setting, lighting, costume and even make-up. These categories can be visualized in Table 1 .

Table 1 - Categories of character and background for theatrical AD

\begin{tabular}{|l|l|l|}
\hline \multirow{2}{*}{ CHARACTER } & Physical aspect & Hair \\
\cline { 3 - 3 } & & Size \\
\cline { 2 - 3 } & Acting & Age \\
\cline { 2 - 3 } & & Gesture \\
\cline { 2 - 3 } & Costume & Facial expression \\
\cline { 2 - 3 } & & (no subitem) \\
\hline
\end{tabular}




\begin{tabular}{|l|l|l|}
\hline & Make-up & (no subitem) \\
\hline \multirow{2}{*}{ BACKGROUND } & Setting & (no subitem) \\
\cline { 2 - 3 } & Lighting & (no subitem) \\
\hline
\end{tabular}

Source: authors' own design.

Although physical aspects are self-explaining (hair, age and size), the term acting deserves some explanation. Aural aspects such as intonation, voice quality and speech rhythm do not have to be translated in AD scripts. That is why these features were excluded in the analysis. Among Pavis's categories (2011), only gesture and facial expressions remained. Theatrical gesture and facial expressions are like two sides of the same coin. Pavis (2011: 184) defines gesture in a broad way, strongly connected to characters' actions and movements. For him, gesture expresses emotion, reaction and meaning (psychic content) through the actor's body.

Examining costume, Pavis (2015) gives it two functions: characterization and identification of characters, and localization of action and gestus 9 . He claims that costume reading happens through repetition and comparison, similarity and contrast. Make-up serves to reinforce facial features, to codify the play esthetically or to awaken the spectator's subconscious.

Concerning background categories, we begin with setting. Its functions are: illustrative and figurative (choice of objects and places); constructive and transformative (choice of a platform for actors' performances); and of subjectivation (a game of colors, lights, which suggest a certain atmosphere and fantasy). Settings include accessories and objects. The last category refers to lighting. For Pavis (2015), it visually brings scene and characters into existence. Color renders emotion to the play. It also interferes with scenography, costume, make-up and gesture.

Some examples will be presented below to deepen our understanding of what happens in our corpus, as regards each type of co-occurrence between appraisal and $A D$ narratological elements. We have selected five examples of gesture, followed by excerpts of costume and lighting (three of each).

\footnotetext{
${ }^{9}$ According to Pavis (2011), scenic action assumes a certain social attitude between the characters which he calls social gestus (servility, equality, violence, cunning etc.).
} 
Beginning with gesture versus 'attitude', the first example shows when Aunt Carola is being introduced to the spectator as a maternal person. She is shown playing with Miralu and Papito. Here is the insertion we commented on:

(8) The aunt adorns Miralu's hair with a red ribbon lace. ${ }^{10}$

Aunt Carola's action (her gesture) demonstrates affectionate attention, i.e., indirectly, positive feelings ('attitude'). The audio description chooses to translate this action in a positive way, so that it can be contrasted with her posterior change of behavior. However, the description also refers to an object (red ribbon lace) which is part of Miralu's costume. We inferred that the importance of this scenic element is emphasized by the evaluative stance.

The second example shows the first appearance of Lucrécio.

(9) He has a nervous twitch. He frequently touches his shoulder to his ear while speaking. ${ }^{11}$

Despite being a description about a movement (part of theatrical gesture), it also tells us something negative and important about the uncle's personality and behavior ('attitude'). Indeed, he seems to be stressed and disturbed, so that it gives us a hint of his change along the plot.

Moving to the excerpts that show gesture and 'graduation', we have:

(10) She finally catches Neco. ${ }^{12}$

This scene shows Papito, dressed as a superhero, responding to Miralu's call for Neco's rescue from an imaginary monster attack. The utterance refers to the moment Papito puts Neco in Miralu's hands, after having played with it and put it out of Miralu's reach, taking advantage of her blindness. There is graduation because "finally" quantifies the act of catching in an imprecise manner. It also intensifies the process ('graduation'). At the same time, the act of catching Neco is also a scenic gesture as part of interpretation.

\footnotetext{
${ }^{10}$ Source text: A tia enfeita o cabelo de Miralu com um laço de fita vermelho.

11 Source text: Ele tem um tique nervoso. Encosta o ombro na orelha várias vezes, enquanto fala.

${ }^{12}$ Source text: Ela finalmente pega Neco.
} 
Another example of 'graduation' and gesture is the following excerpt.

(11) Neco whispers in Miralu's ear. Miralu dances with Neco. She holds it by its arms. She embraces it. Miralu crouches down and talks to Neco. Describe Miralu's movements with Neco on stage. ${ }^{13}$

Miralu talks to her puppet and confesses her wish to see perfectly. It is a moment of complicity. The category of 'graduation' is present in the verbal process "whispers". The verbal choice involves the idea of proximity and it diminishes the level of sound. The whole utterance is full of scenic gesture, represented by verbs.

In our corpus, audio descriptions of gesture are the only ones that include 'engagement'. Example 12 describes Miralu and Papito's playing. He imagines himself saving her from monsters, however, he simultaneously benefits from her disability, playing with Neco without her permission.

(12) He pretends to give Neco to Miralu, but instead he just plays

with it, taking advantage of the fact that she does not see well. ${ }^{14}$

It is an occurrence of 'engagement'-'heteroglossic', since there is a counter expectancy signaled by "but instead" and a negation "she does not...". The verbal processes "pretends to give" and "just plays with" are translations of gestures that the actor makes.

Now the excerpts related to costume will be examined. In example 13, Miralu reaches the climax of the frightening vision of her family. Uncle Lucrécio has just been transformed into a vampire. When Miralu asks for her aunt's help, she actually comes, but transformed into a scary figure. It is what the $A D$ shows:

(13) Aunt Carola appears as a witch, holding an apple ${ }^{15}$.

\footnotetext{
${ }^{13}$ Source text: Neco sussurra no ouvido da Miralu. Miralu dança com Neco. Ela o segura pelos braços. Ela o abraça. Miralu se agacha e conversa com Neco. Descrever os movimentos de Miralu com Neco no palco.

${ }^{14}$ Source text: Ele finge entregar Neco à Miralu, mas aproveita para brincar já que ela não o enxerga direito.

${ }^{15}$ Source text: Tia Carola aparece como uma bruxa, segurando uma maçã.
} 
The witch costume symbolizes the aunt's bad behavior. In previous dialogues, Carola confesses her secret desire to get rid of her niece, as the aunt considers her as an encumbrance to her family. There are two stances of evaluation, one about a negative emotion and another about bad behavior ('attitude').

In example 14, the evaluative stance related to costume is also a negative judgement of behavior ('attitude'). Papito is dressed as an "avemon", which is a monster invented by himself to scare Miralu. The costume characterizes abnormality as we can see below:

(14) Papito comes in to play and climbs onto the pouffe. He wears a mask with an enormous golden beak and a black cloak. ${ }^{16}$

Another example related to costume that deserves attention is:

(15) The other wears lilac pants and blouse, a necklace and a belt full of colored stones, a lilac mantle and a conical hat folded at the end. ${ }^{17}$

We identified the presence of 'graduation' when the costume is described as "full of", since it is an imprecise measure. The costume also represents a behavior: the goodness and the magical power of the wizard Magolino who comes to free Miralu from her blindness.

The references related to lighting (examples 16 and 17) illustrate the way the $A D$ script uses them along the story. These examples show the part of the plot where Miralu misuses the magic telescope and has to deal with the dark side of each person. The plot is built to evidence the contrast between the bad and the good sides ('attitude'). Red lights mean bad behavior and white ones, good conduct.

(16) Red lights. Papito changes. ${ }^{18}$

(17) White lights. Papito returns to normal. ${ }^{19}$

\footnotetext{
${ }^{16}$ Source text: Papito entra em cena e sobe no pufe. Ele usa uma máscara com um enorme bico dourado e uma capa preta.

17 Source text: 0 outro usa calça e blusão lilás, um colar e um cinto cheio de pedras coloridas, um manto lilás e um chapéu em forma de cone e com a ponta dobrada.

${ }^{18}$ Source text: Luzes vermelhas. Papito se transforma.

${ }^{19}$ Source text: Luzes brancas. Papito volta ao normal.
} 
These are qualities added to lighting by association and emphasized by repetition in the corpus.

In the script, lighting is also associated to 'graduation'. This is the case of example 18

(18) Miralu prepares to use the telescope. She puts it near her chest and on her right eye. Miralu finally fastens the telescope on her eye. An intense light scans the stage. ${ }^{20}$

The word "light" is intensified by the adjective "intense" in an imprecise way ('graduation'). We also see a 'graduation' in the use of "scans" instead, for instance, of "goes through". The verb chosen gives us an idea of "in detail". These ideas are linked to the scenic element of lighting.

Having understood how narratological elements appear in the theatrical audio description and how they are related to evaluative stances, the research method will be discussed.

\section{Method}

This research has a corpus-based methodological framework. For the purpose of analysis, the script was divided into insertions, which are the basic unities of $A D$ inserted between each character's speech. The procedures were divided in four stages: 1. tagging; 2. quantitative analysis through the software WordSmith Tools 6.0; 3. qualitative analysis; and 4. discussion of the results. In the first stage, the corpus was tagged manually without any software aid. The tags followed the Appraisal System (AS) categories of 'attitude', 'engagement' and 'graduation', up to the second level of delicacy. The tags can be visualized in Tables 2, 3 and 4 .

${ }^{20}$ Source text: Miralu se prepara para usar a luneta. Ela a coloca junto ao peito. Depois em seu olho direito. Miralu finalmente fixa a luneta no olho. Uma intensa luz branca varre o palco. 
Table 2 - Tags to identify the categories of 'attitude' up to the second level of delicacy

\begin{tabular}{|l|l|}
\hline Tag & Category \\
\hline$<$ ATIT_AFE $>$ & identify ATTITUDE affect \\
\hline$<$ ATIT_JUL> & identify ATTITUDE judgement \\
\hline$<$ ATIT_APR> & identify ATTITUDE appreciation \\
\hline$<$ ATIT_POS $>$ & identify ATTITUDE positive \\
\hline$<$ ATIT_AMB $>$ & identify ATTITUDE ambiguous \\
\hline$<$ ATIT_NEG $>$ & identify ATTITUDE negative \\
\hline$<$ ATIT_INS $>$ & identify ATTITUDE inscribe \\
\hline$<$ ATIT_EVO> $>$ & identify ATTITUDE evoke \\
\hline$</>$ & tag that indicates the end of an excerpt \\
\hline
\end{tabular}

Source: authors' own design.

Table 3 - Tags to identify the category of 'engagement' up to the second level of delicacy

\begin{tabular}{|l|l|}
\hline Tag & Category \\
\hline$<$ ENG_MON $>$ & identify ENGAGEMENT monoglossic \\
\hline$<$ ENG_HET $>$ & identify ENGAGEMENT heteroglossic \\
\hline$</>$ & label that indicates the end of an excerpt \\
\hline
\end{tabular}

Source: authors' own design.

Table 4 - Tags to identify the category of 'graduation' up to the second level of delicacy

\begin{tabular}{|l|l|}
\hline Tag & Category \\
\hline$<$ GRA_FOR $>$ & identify GRADUATION force \\
\hline$<$ GRA_FOC $>$ & identify GRADUATION focus \\
\hline$<$ GRA_AUM $>$ & identify GRADUATION up-scale \\
\hline$<$ GRA_DIM> & identify GRADUATION down-scale \\
\hline$</>$ & label that indicates the end of an excerpt \\
\hline
\end{tabular}

Source: authors' own design. 
The second stage consisted of quantifying the occurrences of evaluative stances, using the Concord tool in WordSmith Tools 6.0. The software analyzed a Notepad version of the annotated corpus. It identified each evaluation in context and calculated the number of their occurrences. The third step was qualitative and consisted of explaining each evaluation (MARTIN: WHITE 2005) and of relating them to theatrical categories. For this purpose, we created theatrical categories and their correspondent tags (Table 5).

Table 5 - Tags to identify categories of characters and background for theatrical $A D$

\begin{tabular}{|l|l|}
\hline Tag & Category \\
\hline$<$ CH_PA_HAIR> & Identify CHARACTER physical aspects hair \\
\hline$<$ CH_PA_SIZE $>$ & Identify CHARACTER physical aspects size \\
\hline$<$ CH_PA_AGE $>$ & Identify CHARACTER physical aspects age \\
\hline$<$ CH_AC_GEST $>$ & Identify CHARACTER acting gesture \\
\hline$<$ CH_AC_FACEX> & Identify CHARACTER acting facial expression \\
\hline$<$ CH_COS> & Identify CHARACTER costume \\
\hline$<$ CH_MAK> & Identify CHARACTER make-up \\
\hline$<$ BAC_SET> & Identify BACKGROUND setting \\
\hline$<$ BAC_LIGH> & Identify BACKGROUND lighting \\
\hline
\end{tabular}

Source: authors' own design.

The last stage was the discussion, which consisted in connecting the two types of categories and examining their implications for theatrical audio description.

\section{Findings}

Miralu and the Magic Telescope's script presents 173 evaluative stances among 1.645 words. Most of them, that is, 143 or $82.66 \%$ express 'attitude'. They are followed by those of 'graduation' ( 23 stances), representing $13.30 \%$. 
And there are only 7 stances of 'engagement', representing $4.05 \%$ of the whole.

Evaluation about feelings was predominant and can be related to emotion, esthetic and ethical aspects ('attitude'). Engagement and graduation were not regarded as being relevant in the script. Table 6 summarizes this information.

Table 6 - Summary of occurrences of evaluation stances in corpus

\begin{tabular}{|l|l|l|l|}
\hline Types of evaluation & $\begin{array}{l}\text { Types of 'attitude'/ } \\
\text { 'engagement'/ 'graduation' }\end{array}$ & $\begin{array}{l}\text { Number } \\
\text { occurrences }\end{array}$ & Percentage \\
\hline \multirow{2}{*}{ 'attitude' } & 'appreciation' & 53 & $30.63 \%$ \\
\cline { 2 - 4 } & 'affect' & 57 & $32.95 \%$ \\
\cline { 2 - 4 } & 'judgement' & 33 & $19.07 \%$ \\
\hline Total of 'attitude' & & 143 & $82.66 \%$ \\
\hline \multirow{2}{*}{ 'engagement' } & 'heteroglossic' & 7 & $4.05 \%$ \\
\cline { 2 - 5 } & 'monoglossic' & 0 & $0 \%$ \\
\hline Total of 'engagement' & & 7 & $4.05 \%$ \\
\hline 'graduation' & 'force' & 23 & $13.30 \%$ \\
\cline { 2 - 5 } & 'focus' & 23 & $13.30 \%$ \\
\hline Total of 'graduation' & & 173 & $100 \%$ \\
\hline TOTAL & & 0 & $0 \%$ \\
\hline
\end{tabular}

Source: authors' own design.

Most 'attitude' stances (57) were about emotions ('affect') followed by esthetical ones ( 53 of 'appreciation') and by ethical ones (33 of 'judgement'). Most of these feelings, i.e. 90, were explicit ('inscribe') instead of implicit ('invoke'), 42. The stances of 'attitude' were balanced in regard to polarity, with almost the same number: 49 were 'positive'; 47 were 'negative'; and 47 were 'ambiguous'. 
Analyzing just emotions ('affect'), they were mostly 'positive' (36 of 57) and implicit - 'invoke' (35). Concerning esthetic feelings ('appreciation'), they were largely 'ambiguous' (46 of 53), but explicit - 'inscribe' (47). In terms of ethic feeling ('judgement'), most of them (23 of 33) were 'negative' as well as explicit - 'inscribe’ (20).

By highlighting 'graduation' stances, we found all of them (23) were evaluated as 'force', which means that some words enhanced or diminished intensity or quantification of other ideas. However, none graded prototypicality of something ('focus'). Sixteen occurrences were categorized as increasing 'force' ('up-scale'). As to the dialogic aspect of our corpus ('engagement'), only 7 stances were characterized as 'heteroglossic', but no occurrence of categorical assertion was seen (no 'monoglossic' stance).

The other categories analyzed were related to theatrical narrative. There were 206 references to scenic language in the audio description. Among those, 151 (73.17\%) were about characters and 55 (26.83\%) about background. Among characters traits, gestures were massively represented with 109 occurrences, followed by costumes (30), age (4), facial expressions (4) and hair (3). Among background descriptions, 34 occurrences were about setting and 21 about lighting.

Co-occurrences of scenic descriptions and appraisal total 166. Overall, we can conclude that descriptions related to scenic language were found evaluative in different proportions when referring to gesture (73\% of 166 or 43.98 ), costumes (42 or $25.30 \%$ ), lighting (40 or $24.10 \%$ ), settings ( 5 or $3.02 \%$ ), facial expression ( 4 or $2.40 \%$ ), hair ( 2 or $1.20 \%$ ) and age (zero). The data can be visualized in Table 7.

Table 7 - Summary of co-occurrences of scenic language and evaluation in corpus

\begin{tabular}{|l|l|l|}
\hline Type of scenic element & Number of co-occurrences & Percentage \\
\hline Gesture & 73 & $43.98 \%$ \\
\hline Costume & 42 & $25.30 \%$ \\
\hline Lighting & 40 & $24.10 \%$ \\
\hline
\end{tabular}




\begin{tabular}{|l|l|l|}
\hline Setting & 05 & $3.02 \%$ \\
\hline Facial expression & 04 & $2.40 \%$ \\
\hline Hair & 02 & $1.20 \%$ \\
\hline Age & 00 & $00 \%$ \\
\hline TOTAL & 166 & $100 \%$ \\
\hline
\end{tabular}

Each of these numbers represents the co-occurrences connecting a theatrical element described and one or more evaluative stances. Out of 166 co-occurrences, 138 were of 'attitude', 22 of 'graduation' and 6 of 'engagement'.

\section{Discussion}

Considering these figures, it can be assumed that the corpus is not neutral, having a great percentage of evaluation, since, among 82 insertions, 57 (or $69,51 \%$ ) manifest subjectivity (total of 173 occurrences). There is also a huge presence of descriptions of theatrical elements (total of 206), among those there are 166 (or 80,58\%) co-occurrences of subjective stances and descriptions of theatrical elements.

On the one hand, there is evidence that, once again, audio description tends to be evaluative, confirming previous studies. On the other hand, this seems to corroborate the idea defended by Jiménez Hurtado (2010), even though we have transposed it to theatrical $A D$, that audio descriptions follow the narrative of the original product (film or play) they accompany, prioritizing narratological elements.

Most of the subjective stances are about emotional aspects $(32,94 \%$ of 'attitude'-'affect') or judging behavior (19,07\% of 'attitude'-‘judgement'), whether they are positive or negative. We notice that these 'attitude' stances are fundamental to making contrast between the stages of narrative, as characters evolve from their good to their bad facets, in the perspective given by the magic telescope. Another part of the corpus is categorized as 
'attitude'-'appreciation' (30,63\%) which concerns esthetic feelings that can easily be directly related to scenic description. These descriptions of feelings are also graduated (13,29\% of 'graduation'), being quantified or intensified mostly in an up-scaled mode. We understand this finding as an indication of an attempt to emphasize subjectivity.

The high number of co-occurrences indicates they are probably intentional. We consider that it converges with Fresno et al (2016), when they link memorization and subjective audio descriptions. Indeed, since subjectivity contributes to constructing meaning, it cooperates to build the story that is being told, for instance, the characters' changes during the plot (from good people to bad ones), leading to destruction of the magic telescope by Miralu. Perhaps, for this reason, gestures (109) and costumes (30) are the most prominent, as they support behavior and feeling descriptions, not only concretely but also symbolically.

The analysis of the examples reveals that, in our corpus, the scenic element helps in constructing the narrative. Gestures are usually related to verbal processes that build our perception of the characters' behaviors and feelings, as can be seen in examples 8 to 11 . Costumes and lighting commonly typify characters' personalities and changes along the plot (see examples 13 , $14,15,16,17$ and 18). We notice that the description of setting concerns with esthetic meaning and that information about facial expression refers to emotions. Finally, hair description could be linked to esthetic and emotional aspects.

\section{Conclusion}

Our findings and discussion confirm the adequacy of the corpus-based method to our defined aims. They also reinforce that the Appraisal System is appropriate to analyze the manifestation of evaluative stances in audio 
description scripts. Furthermore, we understand that the categories created from theatrical mise en scène, in the perspective of Pavis $(2011,2015)$, were also adequate.

Considering what this article has discussed until now, it is possible to state that the script analyzed is not neutral, confirming the findings of previous studies (PRAXEDES FilHo; MAGALHÃES 2013, 2015). For us, it is also clear that the narratological framework has helped in understanding theatrical $A D$, as it had already done with filmic AD (JIMÉNEZ HURTADO 2010).

In addition, there is evidence of the relation between evaluative stances and the highlight of narrative elements. This seems to confirm the findings of Fresno et al (2016), who point out that the most "semantic meanings" in audio description are the most memorized, and Vercauteren and Remael (2014) who defend that ADs with symbolic function must be more robust interpretatively. In this sense, we understand that probably, and consciously or not, the $A D$ script analyzed joins narrative elements to appraisal in order to emphasize them.

Due to the space limitation of an article, it was not possible to show an interesting point we identified. In our understanding, the theatrical play Miralu and the Magic Telescope has clear stages (similar to orientation/complication/evaluation/resolution) like those pointed by discourse semantics as a feature of narrative genres (MARTIN; ROSE 2007). We noted that these stages seem to reflect in the $A D$ script as suggested by Jiménez Hurtado (2010).

In this sense, we propose that future research could aim at describing stages of a theatrical or filmic text with audio description, using the Appraisal System or other systems, according to Martin and Rose's (2007) approach. This description could help define the $A D$ genre, providing tools to guide future audio descriptions, especially with respect to prioritization of what to describe. Another point is that, as we have adapted the narratological categories proposed by Jiménez Hurtado (2010) to theatrical narrative (PAVIS $2011,2015)$, we suggest the search of new theoretical contributions, that 
could contemplate the features of different types of audio description (of opera, of pictures, of monuments, of statues, etc.). 


\section{Acknowledgments}

We would like to thank the Coordenação de Aperfeiçoamento de Pessoal de Nivel Superior (CAPES) for the funding of this research in the scope of a master's degree at Universidade Estadual do Ceará (UECE).

\section{References}

ABUD, J. V. T. Análise do roteiro de audiodescrição da peça Miralu e a Luneta Encantada: um estudo descritivo via Sistema de Avaliatividade. (Master's thesis) Universidade Estadual do Ceará, 2018.

ARRAES, D. de A. A (falta de) reconstrução de programas de efeitos em roteiros de audiodescrição de filme via posicionamentos avaliativos do audiodescritor: um estudo de caso. (Master's thesis) Universidade Estadual do Ceará, 2017.

Araújo, V. L. S; Praxedes Filho, P. H. L; Abud, J. V. T. Análise do roteiro de audiodescrição da peça Miralu e a Luneta Encantada via sistema de avaliatividade. In: MAYER, F.; PINTO, J. (Org.). Perspectivas contemporâneas em audiodescrição. Belo Horizonte: PUC Minas, 2017. p. 73-83.

AUdio DesCription COALITION. Standards for audio description and code of professional conduct for describers. Washington, DC: NPS, 2008)

FARIAS JÚNIOR, L. R. $O$ roteiro de $A D$ em português do filme 'Ensaio sobre a cegueira': um estudo descritivo sobre o estilo avaliativo do texto. (Master's thesis) Universidade Estadual do Ceará, 2016.

Fresno, N.; Castellà, J.; Soler-Vilageliu, O. What should I say? Tentative criteria to prioritize information in the audio description of film characters. In: Matamala, A.; Oreno, P. (Ed.). Researching Audio Description: new approaches. London: Palgrave Macmillan, 2016. p. 143-168.

GONANT, F; MORISSET, L. L'audiodescription: principes et orientations. In: Charte de Qualité de l'Audiodescription. Paris: Conseil Supérieur de L’Audiovisuel, 2008.

HaLlidAY, M. A. K. Language as social semiotic: the social interpretation of language and meaning. London: Edward Arnold, 1978. 
Jimenez HuRTADo, C. Un corpus de cine: teoría y práctica de la audiodescripción. Granada: Tragacanto, 2010.

LIMA, A. K. F. A audiodescrição de monumentos de Fortaleza: um estudo sobre o estilo interpretativo da perspectiva da assinatura avaliativa da audiodescritora. (Undergraduate Monograph) Universidade Estadual do Ceará, Fortaleza, 2016.

MARTIN, J. R., ROSE, D. Working with Discourse - meaning beyond the clause. London: Continuum, 2007.

MARTIN, J. R.; WhITE, P. R. R. The language of evaluation: appraisal in English. New York: Palgrave Macmillan, 2005.

MAZUR, I. Gestures and facial expressions in audio description. In: MASZEROWSKA, A.; Matamala, A.; Orero, P. (Ed.). Audio description: new perspectives illustrated. Amsterdam: John Benjamins Publishing Company, 2014. p. 179-198.

OlIVEIRA JúNIOR, J. N. de. Desmistificando a neutralidade em AD via Sistema de Avaliatividade: um estudo exploratório-descritivo sobre a assinatura avaliativa do audiodescritor de curtas de temática LGBT. (Doctoral dissertation) Universidade Estadual do Ceará, 2016.

Oliveira JúNIOR, J. N. de; PraXedes Filho, P. H. L. A (não)neutralidade em roteiros de audiodescrição-AD de filmes de curta-metragem via sistema de avaliatividade. In: CARPES, D. S. (Org.). Audiodescrição: práticas e reflexões. Santa Cruz do Sul: Catarse, 2016. p. 22-36.

PAVIS, P. A análise dos espetáculos: teatro, mímica, dança, dança-teatro, cinema. São Paulo: Perspectiva, 2015.

PAVIS, P. Dicionário de teatro. São Paulo: Perspectiva, 2011.

Praxedes Filho, P. H. L.; Magalhães, C. M. Audiodescrições de pinturas são neutras? Descrição de um pequeno corpus em português via Sistema de Avaliatividade. In: PonTES, V. de O. et al. (Org.). A tradução e suas interfaces: múltiplas perspectivas. Curitiba: CRV, 2015. p. 99-130.

Praxedes Filho, P. H. L.; Magalhães, C. M. (2013) A neutralidade em audiodescrições de pinturas: resultados preliminares de uma descrição via teoria da avaliatividade. In: ARAújo, V. L. S.; AdERALdo, M. F. (Org.). Os novos rumos da audiodescrição no Brasil. Curitiba: CRV, 2013. p. 73-87.

Praxedes Filho, P. H. L.; Santos, S. A. dos; Farias Júnior, L. R. Tendência de assinatura avaliativa: um estudo de caso exploratório em roteiro de 
audiodescrição de peça de teatro. Entrepalavras, Fortaleza, 7, p. 243265, Aug./Dec., 2017.

Praxedes Filho, P. H. L.; Silva, C. F. da. A (in)existência do parâmetro de neutralidade: um estudo de caso descritivo de audiodescrições fílmicas francesas via Teoria da Avaliatividade. Revista Letras $e$ Letras, v. 30, n. 2, 367-400, Jul/Dec. 2014. Retrieved from:

<http://www.seer.ufu.br/index.php/letraseletras/article/view/27990 >. Accessed Feb. 012018.

SILVA, C. F. da. (2014) A (in)existência do parâmetro de neutralidade: um estudo de caso descritivo de audiodescrições fílmicas francesas via teoria da avaliatividade. (Master's thesis), Universidade Estadual do Ceará, 2014.

Vercauteren, G.; Remael, A. Spatio-temporal setting. Maszerowska, A.; Matamala, A.; Orero, P. (Ed.). Audio description: New Perspectives Illustrated. Amsterdam: John Benjamins Publishing Company, 2014. p. 61-80.

Recebido em: 13/02/2020

Aceito em: $22 / 10 / 2020$

Publicado em novembro de 2020 